\title{
NEONATAL DEATH AND MASSIVE PULMONARY HAEMORRHAGE IN JAMAICA
}

\author{
BY \\ MARIGOLD J. THORBURN \\ From the Department of Pathology, University Hospital of the West Indies, Jamaica
}

(RECEIVED FOR PUBLICATION MAY 21, 1963)

Massive pulmonary haemorrhage in the newborn is a well-recognized but little understood condition, characterized by the presence in the alveoli and alveolar ducts, and sometimes in the interstitial spaces, of large numbers of erythrocytes. The distribution of haemorrhage may be patchy or confluent causing consolidation, as distinct from the petechial haemorrhages seen in infants dying after premature separation of the placenta, or the septal haemorrhages seen in stillbirths. The condition was probably first described by Browne (1922a) who found it in eight infants of a series of 153 neonatal deaths (1922b). He concluded that 'acute haemorrhagic pneumonia', as he called it, was a distinct entity, causing sudden death in full-term and premature infants, and caused by an overwhelming infection or an anaphylactic reaction. A study of 4,000 autopsies by Ahvenainen and Call (1952) revealed 67 cases of infants with massive pulmonary haemorrhage, $77 \%$ of whom were less than 15 days old. These cases included lungs showing any type of haemorrhage. The incidence of pulmonary haemorrhage reported by Sivanesan (1961) from Singapore was $8 \%$ of neonatal deaths and was the third most common pathological observation in the lungs. The frequent occurrence of massive pulmonary haemorrhage and the lack of knowledge of its pathogenesis prompted an investigation of the cases occurring in the University of the West Indies in order to discover whether any further suggestions could be made to elucidate the aetiology. The results of this investigation and a discussion of the possible aetiological factors form the subject of this paper.

\section{Materials and Methods}

Between July 1953 and June 1962, 2,950 autopsies were performed at the University Hospital of the West Indies, of which 336 were neonatal deaths and 231 were stillbirths. In this period there were 14,013 births in the obstetric unit and domiciliary service, of which 304 were stillborn and 301 died in the neonatal period. The additional autopsies on newborns were performed on infants from other hospitals in Kingston. The population served by the hospital is multiracial: there is some selection, as the majority of patients come from the poorer classes. The racial constitution of the autopsy population (Bras, Brooks and Watler, 1961) is Negro or mixed $-97.2 \%$, White- $1.2 \%$, Chinese $-0.8 \%$ and East Indian- $0.8 \%$.

Method of Examination. The autopsy records of all the perinatal deaths were examined and all cases mentioning the presence of pulmonary haemorrhage of any type were scrutinized. The clinical records, gross autopsy findings and microscopic sections were examined. Lung sections were available from all autopsies. Blocks of lung tissue had been fixed in $10 \%$ neutral buffered formalin and embedded in paraffin wax. Sections were stained with haematoxylin and eosin.

Conditions of Study. Criteria for selection were as follows:

1. Death occurred in the first or second week of life; stillbirths were excluded.

2. Haemorrhage into the lungs was judged to be severe enough to be the cause of death from respiratory embarrassment. This was difficult to assess in a retrospective survey, as the degree of importance given to the presence of pulmonary haemorrhage varied considerably among the prosectors.

On the assumption that the lung weight should be increased in cases of massive pulmonary haemorrhage, the lung weights of the selected infants were compared with the average lung weights as given by Potter (1952a). Rather surprisingly, the weights in some of the cases of pulmonary haemorrhage were less than average. However, the average weight of the lungs in Jamaican babies is less than the average given by Potter, as shown in Fig. 1. Fig. 1 shows the average lung weights of Jamaican babies for each range of $500 \mathrm{~g}$. of body weight and compares them with Potter's figures. Three infants thought to have massive pulmonary haemorrhage were below the average. They were, however, included on the basis of gross description and microscopical evidence. 


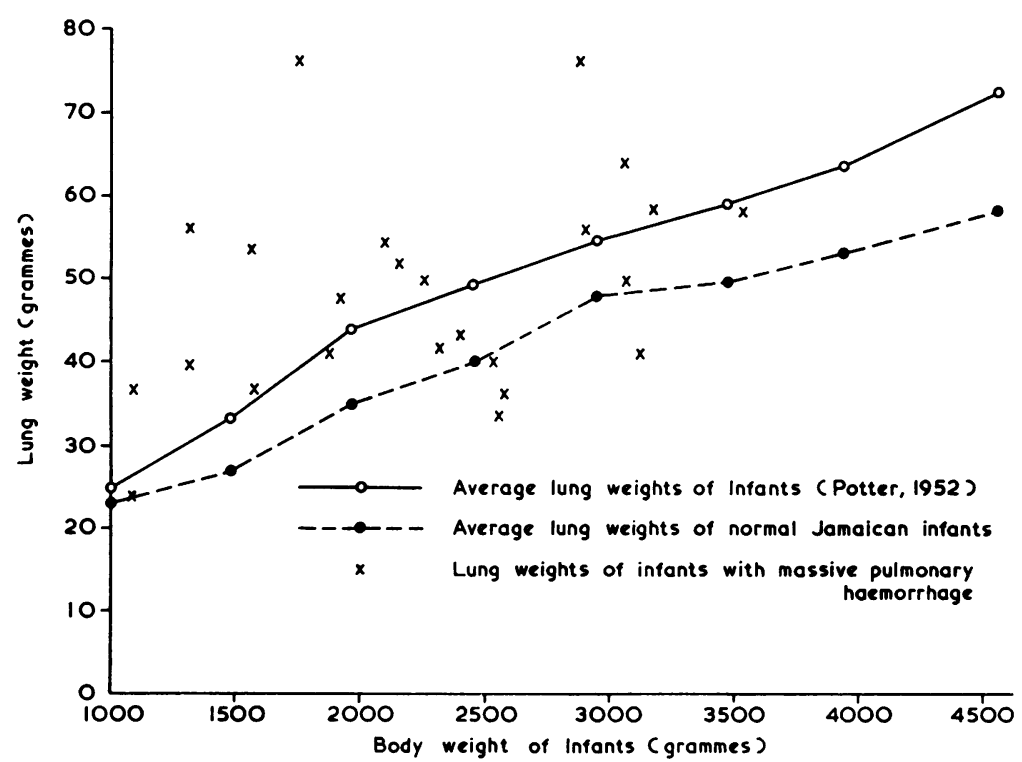

FIG. 1.-Comparison of lung weights of infants with pulmonary haemorrhage with normal infants.

3. Bronchopneumonia was absent as judged by lack of acute inflammation. Browne (1922a) considered infection to be one of the most important causes of pulmonary haemorrhage, even though there may be no acute inflammatory changes in the lungs. Patchy haemorrhages may be seen in the lungs of infants dying of bronchopneumonia, but this feature should not be confused with massive pulmonary haemorrhage, where only a few inflammatory cells are encountered. These two entities were therefore separated, and only cases of pulmonary haemorrhage were examined further.

\section{Results}

Twenty-seven cases were considered to satisfy the criteria of selection. They could be divided into two main groups on the basis of having pulmonary haemorrhage alone or pulmonary haemorrhage associated with other potentially fatal lesions. There were 19 in the first group and eight in the second. The clinical and pathological details are summarized in Tables 1 and 2.

\section{Clinical Observations}

(a) Maternal Features. The age distribution and parity of the mothers did not show any deviation from the pattern encountered in normal births. Seven mothers in the series had severe pre-eclamptic toxaemia, necessitating caesarean section in three and progressing to post-partum eclampsia in one. Eleven mothers had abnormal deliveries. One had a difficult forceps delivery for deep transverse arrest and foetal distress. There were four twin preg- nancies. One required caesarean section for prolapsed cord and the first twin was the infant affected. In another case, the second twin died after an internal version and breech extraction. In a third, the first twin died after an assisted breech delivery, and in the fourth there was a delay of 40 minutes before the second twin was delivered, and the foetal heart was noted to be weak.

There were six caesarean sections, four as described above. The remaining two were performed as emergencies for Grade IV placenta praevia. There were four breech deliveries including the twins described above. Other complications included a multigravida who had a 30-minute second stage and who delivered an infant who never respired. The placenta was infarcted. One mother had a precipitate delivery in a taxi and the infant died 18 hours after birth.

(b) Infant Factors. Fourteen infants had severe respiratory distress at birth and most died within the first two days. The remaining 13 infants appeared to be normal at birth, but developed distress later, usually after $\mathbf{4 8}$ hours.

In 10 liveborn infants, in addition to signs of respiratory distress, it was recorded that vomiting or spitting of blood or blood-stained mucus had occurred shortly before death. This is a fairly common occurrence in the first day of life when the infant may vomit ingested maternal blood, but it is of greater significance when it occurs after two or three days. It is then usually interpreted as a sign 
TABLE 1

DEATHS DUE TO PULMONARY HAEMORRHAGE ALONE

\begin{tabular}{|c|c|c|c|c|c|c|c|c|c|c|c|}
\hline \multirow[b]{2}{*}{$\begin{array}{l}\text { Case } \\
\text { No. }\end{array}$} & \multicolumn{4}{|c|}{ Obstetric Factors } & \multicolumn{6}{|c|}{ Infant Data } & \multirow[b]{2}{*}{ Comments } \\
\hline & \begin{tabular}{|c|}
$\begin{array}{c}\text { Type } \\
\text { of } \\
\text { Delivery }\end{array}$ \\
\end{tabular} & $\begin{array}{c}\text { Pre- } \\
\text { eclamptic } \\
\text { Toxaemia }\end{array}$ & $\begin{array}{l}\text { Labour } \\
\text { (hrs.) }\end{array}$ & $\begin{array}{c}\text { Antenatal } \\
\text { Abnormalities }\end{array}$ & $\begin{array}{l}\text { Weight } \\
\text { (g.) }\end{array}$ & $\underset{\text { (wks.) }}{\text { Maturity }}$ & $\begin{array}{c}\text { Age } \\
\text { at } \\
\text { Death }\end{array}$ & $\begin{array}{l}\text { Class } \\
\text { at } \\
\text { Birth }\end{array}$ & $\begin{array}{r}\text { On } \\
\text { Di } \\
\text { Early }\end{array}$ & $\begin{array}{l}\text { of } \\
\text { ess } \\
\text { Late }\end{array}$ & \\
\hline 1 & $\mathbf{F}$ & + & 9 & Deep transverse arrest & 2,200 & 40 & 44 hrs. & C & + & - & \\
\hline 2 & B & - & 16 & $\begin{array}{l}\text { 2nd twin, internal ver- } \\
\text { sion }\end{array}$ & 1,613 & 32 & 2 hrs. & $\mathbf{A}$ & + & - & \\
\hline 3 & $\mathbf{S}$ & - & 2 & Born in taxi & 3,625 & 36 & 4 days & $\mathbf{A}$ & - & + & $\begin{array}{l}\text { Sudden death with } \\
\text { blood in mouth }\end{array}$ \\
\hline 4 & $\mathbf{S}$ & - & $?$ & Born face to pubis & 1,300 & 28 & 10 days & $\mathbf{A}$ & - & + & Sudden death \\
\hline 5 & $\mathbf{S}$ & - & 26 & $\begin{array}{l}\text { Antepartum haemor- } \\
\text { rhage }\end{array}$ & 878 & 27 & 4 days & $\mathbf{A}$ & - & + & $\begin{array}{l}\text { Purpura on 3rd day; } \\
\text { vomited blood }\end{array}$ \\
\hline 7 & $\mathbf{B}$ & - & $1 \frac{1}{2}$ & 1st twin & 2,530 & 40 & 8 hrs. & C-D & + & - & $\begin{array}{l}\text { Vomited blood-stained } \\
\text { mucus }\end{array}$ \\
\hline \multirow[t]{2}{*}{8} & C.H. & - & - & $\underset{\text { praevia }}{\text { Grade IV placenta }}$ & 1,080 & 36 & $40 \mathrm{hrs}$. & $\mathbf{A}$ & + & - & \\
\hline & B & - & 11 & - & 3,170 & 36 & $24 \mathrm{hrs}$. & $\mathbf{D}$ & + & - & \multirow[t]{4}{*}{ Blood in mouth } \\
\hline 10 & $\mathbf{S}$ & ++ & 35 & $\begin{array}{l}\text { P.E.T. in labour; } \\
\text { foetal distress }\end{array}$ & 2,620 & 44 & 17 hrs. & $\mathrm{C}$ & + & - & \\
\hline 11 & C.S. & + & - & $\begin{array}{l}\text { 1st twin, prolapsed } \\
\text { cord }\end{array}$ & 2,440 & $?$ & 20 hrs. & $\mathbf{D}$ & + & - & \\
\hline 12 & $\mathbf{S}$ & - & 23 & $\begin{array}{l}\text { 2nd twin, foetal dis- } \\
\text { tress }\end{array}$ & 2,970 & 38 & $35 \mathrm{~min}$. & D & + & - & \\
\hline 13 & $\mathbf{S}$ & - & 41 & Nil & 3,120 & 40 & $15 \mathrm{hrs}$ & B & + & - & Vomited blood \\
\hline 14 & C.S. & ++ & - & Severe P.E.T. & 2,600 & 35 & 44 hrs. & C & + & + & $\begin{array}{l}\text { Blood-stained mucus in } \\
\text { mouth }\end{array}$ \\
\hline 15 & $\mathbf{S}$ & - & $15 \frac{1}{2}$ & $\begin{array}{l}30 \text { min. } 2 \text { nd stage in } \\
\text { multipara }\end{array}$ & 2,096 & 40 & $25 \mathrm{~min}$. & D & + & - & Placenta infarcted \\
\hline 16 & C.S. & - & - & $\underset{\text { praevia }}{\text { Grade IV placenta }}$ & 1,900 & 34 & $10 \mathrm{~min}$. & D & + & - & \\
\hline 17 & $\mathbf{S}$ & - & $?$ & Anaemia & 3,256 & 37 & 48 hrs. & $\mathbf{A}$ & - & + & $\begin{array}{l}\text { Delivered outside hos- } \\
\text { pital }\end{array}$ \\
\hline 18 & C.S. & ++ & $12 \frac{1}{2}$ & Shirodkar operation & 2,300 & 38 & $3 \frac{1}{2}$ days & D & + & + & $\begin{array}{l}\text { Initial recovery; vomi- } \\
\text { ted blood }\end{array}$ \\
\hline 19 & $\mathbf{S}$ & - & 14 & - & 1,806 & 36 & 9 days & $?$ & - & + & Sudden death \\
\hline 22 & $\mathbf{S}$ & - & $?$ & Born at home & 2,965 & 40 & 10 days & $?$ & - & + & $\begin{array}{l}\text { Pierre-Robin syndrome; } \\
\text { died after vomiting }\end{array}$ \\
\hline
\end{tabular}

$\mathbf{F}=$ Forceps; $\mathbf{S}=$ Spontaneous; C.H. = Caesarean hysterectomy; $\mathbf{B}=$ Breech; C.S. = Lower segment caesarean section; P.E.T. = Pre-eclamptic toxaemia.

of haemorrhagic disease of the newborn. Ahvenainen and Call (1952) noted spitting or vomiting of blood in many of their cases. It is suggested that this sign, when associated with respiratory distress, may be clinical evidence of the presence of pulmonary haemorrhage. Sixteen infants weighed less than $2,500 \mathrm{~g}$. at birth.

Other abnormal cases were an infant with congenital spherocytosis who died two days after a transfusion, and an infant who was admitted because of feeding difficulty due to glossoptosis and micrognathia and died immediately after vomiting at the age of 10 days.
Five infants died suddenly and unexpectedly, having been well until a short time before death.

Pathological Observations. The gross appearance of the lungs in many cases was distinctive. They were heavy, solid and airless, and the areas containing haemorrhage sank in water. They were deep crimson with darker purple areas of more intense haemorrhage. In some cases, the features were apparently not so distinctive, as the diagnosis was not made until histological examination was performed.

Microscopically, large areas of lung were packed 
TABLE 2

CASES WITH OTHER FATAL CONDITIONS

\begin{tabular}{|c|c|c|c|c|c|c|c|c|c|c|c|}
\hline \multirow[b]{2}{*}{$\begin{array}{l}\text { Case } \\
\text { No. }\end{array}$} & \multicolumn{4}{|c|}{ Obstetric Factors } & \multirow[b]{2}{*}{$\begin{array}{c}\text { Weight } \\
\text { (g.) }\end{array}$} & \multirow[b]{2}{*}{$\begin{array}{c}\text { Maturity } \\
\text { (wks.) }\end{array}$} & \multicolumn{2}{|c|}{ Infant Data } & & & \multirow[b]{2}{*}{ Comments } \\
\hline & $\begin{array}{c}\text { Type } \\
\text { of } \\
\text { Delivery }\end{array}$ & $\begin{array}{l}\text { Pre- } \\
\text { eclamptic } \\
\text { Toxaemia }\end{array}$ & $\begin{array}{l}\text { Labour } \\
\text { (hrs.) }\end{array}$ & $\begin{array}{c}\text { Antenatal } \\
\text { Abnormalities }\end{array}$ & & & $\begin{array}{c}\text { Age } \\
\text { at } \\
\text { Death }\end{array}$ & $\begin{array}{l}\text { Class } \\
\text { at } \\
\text { Birth }\end{array}$ & $\begin{array}{r}\text { On } \\
\text { Di } \\
\text { Earl }\end{array}$ & $\begin{array}{l}\text { of } \\
\text { Late }\end{array}$ & \\
\hline 23 & $\mathbf{S}$ & - & $10 \frac{1}{2}$ & - & 1,342 & 36 & $60 \mathrm{hrs}$. & $\mathbf{A}$ & - & + & $\begin{array}{l}\text { Vomited blood; also } \\
\text { had V.S.D. with } \\
\text { coarctation }\end{array}$ \\
\hline 24 & $\mathbf{S}$ & - & 5 & Born in taxi & 3,100 & 40 & $18 \frac{1}{2}$ hrs. & A & + & - & $\begin{array}{l}\text { Adrenal haemorrhage; } \\
\text { ? traumatic }\end{array}$ \\
\hline 25 & B & - & $3 q$ & $\begin{array}{l}\text { Five abortions; easy } \\
\text { delivery }\end{array}$ & 1,510 & 34 & $6 \frac{1}{2}$ days & B-C & - & + & $\begin{array}{l}\text { Jaundice, malrotation } \\
\text { of great vessels; } \\
\text { Staph. aureus cul- } \\
\text { tured after death }\end{array}$ \\
\hline 26 & C.S. & ++ & - & $\begin{array}{l}\text { Hypertensive, severe } \\
\text { pre-eclamptic tox- } \\
\text { aemia }\end{array}$ & 928 & 29 & 4 days & $\mathrm{C}$ & - & + & $\begin{array}{l}\text { Peritoneal and ventri- } \\
\text { cular haemorrhage; } \\
\text { ? haemorrhagic dis- } \\
\text { ease }\end{array}$ \\
\hline 27 & $\mathbf{S}$ & - & $35 \mathrm{~min}$. & $\begin{array}{l}\text { Urinary infection; pre- } \\
\text { cipitate delivery }\end{array}$ & 950 & 31 & 5 days & $?$ & - & + & $\begin{array}{l}\text { Haemoptysis; small } \\
\text { intracranial haemor- } \\
\text { rhage; Staph. aureus } \\
\text { cultured after death }\end{array}$ \\
\hline 28 & $\mathbf{S}$ & - & $10 \frac{1}{2}$ & $\begin{array}{l}\text { Previous stillbirth and } \\
\text { two neonatal deaths }\end{array}$ & 3,170 & 40 & 52 hrs. & C & - & + & $\begin{array}{l}\text { Congenital spherocyto- } \\
\text { sis, transfused on } \\
\text { birthday; subdural } \\
\text { haemorrhage }\end{array}$ \\
\hline 29 & $\mathbf{S}$ & + & $12 \frac{1}{2}$ & Foetal distress & 2,315 & 37 & $26 \mathrm{hrs}$ & C & + & - & $\begin{array}{l}\text { Intracerebral haemor- } \\
\text { rhage }\end{array}$ \\
\hline 31 & $\mathbf{S}$ & $?$ & $?$ & $\begin{array}{l}\text { Born at home; no ante- } \\
\text { natal care }\end{array}$ & 1,102 & $?$ & 5 days & $\mathbf{A}$ & - & + & $\begin{array}{l}\text { Brought to hospital } \\
\text { jaundiced, moribund; } \\
\text { kernikterus, cause } \\
\text { unknown }\end{array}$ \\
\hline
\end{tabular}

$\mathbf{S}=$ Spontaneous; $\mathbf{B}=$ Breech; C.S. = Caesarean section; V.S.D. = Ventricular septal defect.

with red blood cells. In some cases, the distribution was more patchy and in a few the haemorrhage was diffuse. There were also interstitial and septal haemorrhages. In a few cases the presence of haemorrhage was not immediately obvious. The alveoli and alveolar ducts contained a yellow or orange material, which on high-power examination was seen to consist of shadowy lysed erythrocytes containing very little haemoglobin. This finding was prominent in the infant with glossoptosis and in two of the other infants who died suddenly. Lysis of red cells is due to rapid autolysis and if it is observed in an autopsy where the tissues other than the lungs are well preserved, it suggests aspiration of gastric contents (Irons and Apfelbach, 1940). Other pathological observations in the lungs were varying degrees of atelectasis, patchy oedema and the presence of slightly basophilic, 'protein-like' material. This basophilic material was seen in four infants who died suddenly, and in one of these large numbers of bacteria were present in the bronchioles. These appearances were also suggestive of aspirated gastric contents. Eosinophilic material resembling hyaline membranes was present in one case, not only in the alveoli and ducts but also in the bronchioles and smaller bronchi. Several cases showed a mild mononuclear reaction, especially in older areas in association with iron pigment.

Abnormalities in other organs included two cases of severe congenital heart disease, undiagnosed in life, and intracranial haemorrhage, two of which were massive, in three infants. One of the massive haemorrhages was in the infant of a toxaemic mother and the other was in the infant with spherocytosis. Four infants had haemorrhages in other organs, including the adrenals and the peritoneal cavity. One infant had severe kernikterus. Two infants had some evidence of extrapulmonary infection in that Staphylococcus aureus was cultured from the blood at autopsy. One of these infants had malrotation of the great vessels and the other had septic spots on the neck and a small intracranial haemorrhage.

It is apparent that there are a number of conditions associated with pulmonary haemorrhage. The relation between the incidence of these associated conditions and the time of onset of respiratory 


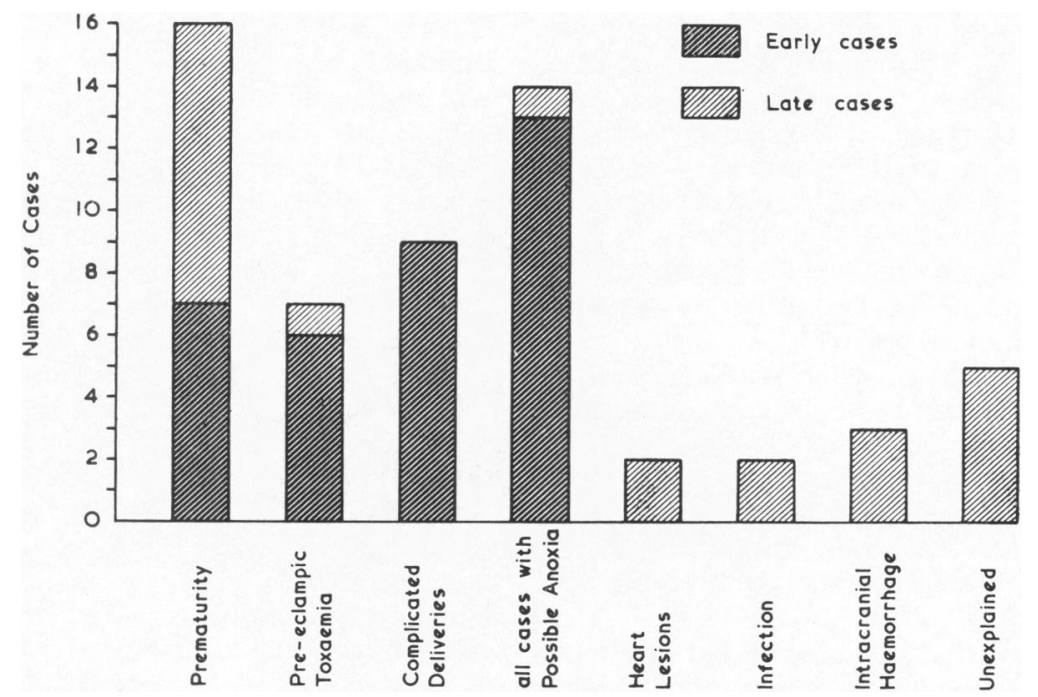

FIG. 2.-Comparison of the frequency of associated conditions in cases with early and late onset of distress.

distress was found to be of some interest. This is presented in Fig. 2.

\section{Discussion}

The incidence of massive pulmonary haemorrhage in this hospital was $8 \%$, a similar figure to those from Singapore (Sivanesan, 1961) and from the United States (Ahvenainen and Call, 1952). It seems, therefore, that this figure of $8 \%$ is what one might expect to find universally. While the cause or causes of massive pulmonary haemorrhage remain unknown, the data presented here indicate that certain factors recur frequently and must therefore play at least a contributory role.

Cases with Early Onset of Distress. There were 14 infants who developed respiratory distress early. Of these, 13 were associated with pre-eclamptic toxaemia, abnormal delivery, or other complications known to predispose to severe anoxia before birth. Severe pre-eclamptic toxaemia is frequently associated with foetal anoxia (Morison, 1952). This, combined with the high incidence of abnormal deliveries, which may be associated with intrapartum asphyxia, suggests that anoxia may have played a part in causing pulmonary haemorrhage in the early group. Potter (1952b) and MacGregor (1939) have suggested that anoxia may cause massive pulmonary haemorrhage. MacGregor (1939), in examining 177 cases of neonatal pneumonia, noted 13 cases of pulmonary haemorrhage unaccompanied by inflammation. She was of the opinion that asphyxia was the most significant factor in producing congestion and haemorrhage in the lungs. Clifford (1941) examined 11 newborn infants who died asphyxial deaths due to placenta praevia. He observed that asphyxia could lead to widespread changes in different organs, causing mainly congestion, oedema, haemorrhage and tissue degeneration. Petechial haemorrhages occurred in many organs, while more severe haemorrhage, sometimes causing consolidation, was seen in the lungs. He concluded that these effects were due to an increased hydrogen-ion concentration in the blood, producing loss of tone of capillaries and small arterioles, allowing escape of plasma and red blood cells. In prematurity (seven premature babies were in the early group) immaturity of vessels may also play a part (Morison, 1952).

Late Onset of Distress. A variety of conditions was associated with late onset of distress. Evidence of infection was present in only two cases. Ahvenainen and Call (1952) considered infection to be the most important cause of pulmonary haemorrhage in their series: the infection in their cases occurred either as pneumonia or was extrapulmonary. If cases of haemorrhagic bronchopneumonia had been included in this series, the number with an infective aetiology would obviously have been higher. However, Stowens (1959) states that bacteriological and virological studies on cases of massive pulmonary haemorrhage usually fail to produce an infective agent. MacGregor (1939) believed that haemorrhage occurred first and provided a good medium for bacterial invasion. 
Two infants had severe heart malformations, undiagnosed in life. The onset of distress and death appeared to be due to the complication of severe pulmonary haemorrhage. Ahvenainen and Call (1952) found this association frequently and suggested that haemorrhage was the result of congestion.

Intracranial haemorrhage was observed in three infants. It was also a frequent finding in Ahvenainen and Call's series. This association is also not infrequently seen in adults.

Haemorrhagic disease of the newborn was not diagnosed in life in any case. In three cases where haemorrhages were present in organs other than the lungs, a haemorrhagic factor could be suggested as the cause of the pulmonary haemorrhage. In all three cases, distress and death ensued between the third and fourth day when the prothrombin time is at its longest.

Erythroblastosis foetalis should be mentioned because of the occasional occurrence of massive pulmonary haemorrhage in this disease, especially in the presence of kernikterus. Kernikterus was seen in one case in this series, but the cause was not determined. Rhesus incompatibility is rare in Jamaica as the percentage of rhesus negative people is only $4 \%$ of the population (P. Milner, 1962, personal communication).

Ahvenainen and Call (1952) had six cases of pulmonary haemorrhage following transfusions, but death occurred within 24 hours. The only infant in this series who had been transfused also had a subdural haemorrhage.

Inhalation of Vomit. One infant was known to have died immediately after vomiting, and small amounts of amorphous basophilic material were seen in the respiratory passages. Five infants died suddenly and no predisposing factors or associated abnormalities were observed, except for appearances in the lungs similar to those in the infant dying after vomiting. In one infant, bacteria were seen in the bronchi, and in two others lysis of red blood cells was noted. Although there was no other definite evidence of inhalation of gastric contents in these five infants, the picture was suggestive of this. Rhaney and MacGregor (1948), in a study of 39 newborn infants with pneumonia due to inhalation of gastric contents, stated that foreign material was only recognizable in cases that were autopsied soon after death. Gardner (1958) stated that the absence of foreign material did not preclude a diagnosis of aspiration even in early cases, and Moran (1953) found that one of the most potent causes of lung damage in aspiration was strong solutions of sugars, which would be unidentifiable.
Rhaney and MacGregor (1948) in their study also described massive pulmonary haemorrhage which was responsible for large areas of consolidation: lysis of red blood cells was striking. They suggested that inhalation of free hydrochloric acid might be a factor in producing massive pulmonary haemorrhage. This hypothesis was strengthened experimentally by Teabeaut (1952). He found that in rabbits the acute reaction to aspiration of gastric contents consisted of oedema and congestion with haemorrhage and diapedesis of red blood cells, and a neutrophil cell response. If the material was free of particulate matter and the $p \mathrm{H}$ above $2 \cdot 5$, only the acute phase occurred. The time that elapsed before death depended on the severity of the response. Recently in this department an autopsy was performed on a young woman who died immediately after a grand-mal seizure. The cause of death was massive pulmonary haemorrhage due to inhalation of gastric contents. Since this series was completed, an infant of 18 days was examined who had had neonatal tetanus. The lungs had a most striking appearance. The alveoli were packed with red blood cells and the alveolar ducts and bronchioles were filled with a slightly basophilic material which was P.A.S. positive. The infant had almost certainly aspirated food which had caused this extreme reaction in the lungs. It might be argued that free acid is not always present in the stomach of the newborn infant, but Miller (1941) has shown that there can be a degree of acidity equivalent to that of an adult. That this is not dependent on birth weight or maturity was demonstrated by Ames (1960): she found that only 5\% of premature babies had no free acid at any time during the first 10 days of life. As it is well recognized that adults with intracerebral disease are liable to aspirate gastric contents (Irons and Apfelbach, 1940; Gardner, 1958), it is reasonable to suggest that pulmonary haemorrhage associated with intracranial haemorrhage in infants has a similar pathogenesis. Although the probable explanation for the frequency of aspiration of vomit in cerebral disease is the supine position in a semicomatose patient, it is also possible that pulmonary haemorrhage has a more direct relation to cerebral disease.

Massive pulmonary haemorrhage appears to be not a single disease entity but a complication of several disorders. The initiating factor causes a haemorrhagic reaction in the lungs which then produces further injury to the infant. This may occur before birth as intrauterine asphyxia and cause the infant to be severely distressed at birth.

After birth, the initiating factor may be infection, congenital heart disease, intracranial haemorrhage, 
kernikterus and possibly aspiration of gastric contents.

\section{Summary}

Examinations were carried out on 27 newborn infants dying with massive pulmonary haemorrhage. Pulmonary haemorrhage occurred in $8 \%$ of neonatal deaths in this hospital: $52 \%$ of cases died early in the neonatal period and $48 \%$ later. Anoxia was considered to be the main causal agent in the majority of early cases. In the later cases several factors were considered responsible.

The author gratefully acknowledges the assistance of Dr. W. B. Robertson for criticizing the manuscript.

\section{REFERENCES}

Ahvenainen, E. K. and Call, J. D. (1952). Pulmonary hemorrhage in infants; a descriptive study. Amer, $J$. Path. 28, 1.

Ames, M. D. (1960). Gastric acidity in the first ten days of life of the prematurely born baby. Amer. J. Dis. Child., 100, 252.

Bras, G., Brooks, S. E. H. and Watler, D. C. (1961). Cirrhosis of the liver in Jamaica. J. Path. Bact., 82, 503
Browne, F. J. (1922a). Pneumonia neonatorum. Brit. med. J., $1,469$.

(1922b) Neo-natal death ibid., 2, 590

Clifford, S. H. (1941). The effects of asphyxia on the newborn infant. J. Pediat., 18, 567.

Gardner, A. M. N. (1958). Aspiration of food and vomit. Quart. J. Med., 27, 227.

Irons, E. E. and Apfelbach, C. L. (1940). Aspiration bronchopneumonia, with special reference to aspiration of stomach content. J. Amer, med. Ass., 115, 584.

MacGregor, A. R. (1939). Pneumonia in the new-born. Arch. Dis. Childh., 14, 323.

Miller, R. A. (1941). Observations on the gastric acidity during the first month of life. ibid., 16, 22.

Moran, T. J. (1953). Pulmonary edema produced by intratracheal injection of milk, feeding mixtures, and sugars. A.M.A.Amer J. Dis. Child. 86, 45 .

Morison, J. E. (1952). Foetal and Neonatal Pathology. Butterworth, London.

Potter, E. L. (1952a). Pathology of the Fetus and the Newborn, p. 13. The Year Book Publishers, Chicago.

- (1952b). ibid., p. 257.

Rhaney, K. and MacGregor, A. R. (1948). Pneumonia in the newborn resulting from inhalation of gastric contents. Arch. Dis. Childh., 23, 254.

Sivanesan, S. (1961). Neonatal pulmonary pathology in Singapore. J. Pediat., 59, 600 .

Stowens, D. (1959). Pediatric Pathology, p. 28. Williams and Wilkins, Baltimore.

Teabeaut, J. R. (1952). Aspiration of gastric contents. An experimental study. Amer. J. Path., 28, 51 